\title{
Predicting Plant Phosphorus Requirements for Hawaii Soils using a Combination of Phosphorus Sorption Isotherms and Chemical Extraction Methods
}

\author{
N. V. HUE AND R. L. FOX \\ Department of Tropical Plant and Soil Sciences, College of Tropical \\ Agriculture and Human Resources, University of Hawaii at Manoa, \\ Honolulu, Hawaii, USA
}

\begin{abstract}
Phosphorus $(P)$ is an essential nutrient for plant growth and reproduction. One of the tasks of soil testing is to identify whether the soil P level is sufficient to meet crop requirements, and if not, to provide an estimate of the quantity of $P$ that must be added for good growth of a given crop. Data for 12 soils (11 series) from Hawaii were used to develop correlations between critical $P$ concentrations in soil solution derived from $P$ sorption isotherms with $P$ extracted with Mehlich 3, Olsen, or modified Truog solutions. Extractable P, in turn, was correlated with $P$ fertilizer requirements. Critical $P$ levels in soil solution reported in the literature for various crops ranged from $0.005 \mathrm{mg} \mathrm{L}^{-1}$ for cassava (Manihot esculenta) to 0.30 for lettuce (Lactuca sativa) and to 1.6 for nonmycorrhizal onions (Allium cepa). The $P$ buffer coefficient, defined as the ratio of fertilizer $P$ added to extractable $P$, averaged 2.2, 4.2, and 8.6 for the modified Truog, Olsen, and Mehlich 3, respectively. Phosphorus requirements for certain crops could be estimated by the following steps: (i) obtaining (possibly one time only) soil solution P levels via $P$ sorption isotherm for a given soil (series or family), (ii) identifying the critical soil solution $P$ for a given crop from the literature, (iii) regressing soil solution $P$ against extractable $P$, and (iv) establishing relationships between extractable $P$ and fertilizer $P$.
\end{abstract}

Keywords Phosphorus, soil fertility, testing methodology

\section{Introduction}

Plants require relatively large quantities of phosphorus (P) for normal growth. Phosphorus is a structural component of plant membranes and deoxyribonucleic and ribonucleic acids (DNA and RNA), which are essential for reproduction, and is essential for energy transfer, mainly via the high-energy compound adenosine triphosphate (ATP) (Marschner 1995).

Phosphorus-deficient plants are stunted, with limited root systems and thin stems. Symptoms include reduced tillering in cereals and in corn, seedlings look stunted and older leaves may be purple because of high levels of anthocyanins

Received 2 April 2008; accepted 11 October 2008.

Address correspondence to N. V. Hue, Department of Tropical Plant and Soil Sciences, College of Tropical Agriculture and Human Resources, University of Hawaii at Manoa, Honolulu, HI 96822. E-mail: nvhue@hawaii.edu 
(purple pigments). Fruit trees deficient in $\mathrm{P}$ have fewer and shorter shoots and malformed fruits and seeds. Thus, not only are yields poor but crop quality also is poor where $\mathrm{P}$ is deficient (Uchida 2000).

Most crops require from 0.2 to $0.5 \% \mathrm{P}$ in tissue dry matter for normal growth, and $\mathrm{P}$ deficiency is likely when the $\mathrm{P}$ content drops below $0.1 \%$ (Hue, Ikawa, and Huang 2000; Jones, Wolf, and Mills 1991).

Although humans and animals can obtain P from various food sources, plants must get their $\mathrm{P}$ from the soil. Efficient management of soil and fertilizer $\mathrm{P}$ requires knowledge of the following:

1. The external P requirement of the plants being grown. This can be described as the necessary concentration of $\mathrm{P}$ in the rooting medium (or soil solution) that provides for optimum production (Asher and Loneragan 1967; Fox 1979). Numerous soil and management factors influence the external $\mathrm{P}$ requirement (Peaslee and Fox 1978). Among the soil factors are (a) buffering capacity of the soil for P; (b) cross-sectional area for diffusion of $\mathrm{P}$ to roots and tortuosity of the diffusion path; (c) soil factors associated with root development, especially root hair proliferation and mycorrhizal associations; (d) mineralization of organic $P$; (e) species and concentration of salts in the soil solution; (f) temperature; and (g) nature of the solid-phase $\mathrm{P}$ as this influences the rate of dissolution of $\mathrm{P}$ compounds. Management factors include (a) volume of soil fertilized and placement of fertilizer with respect to roots, and (b) time of fertilization in relation to expected utilization.

2. The quantity of $\mathbf{P}$ required in the soil to maintain the external $\mathbf{P}$ concentration required by the crop being grown (Fox and Kamprath 1970). Phosphate sorption curves and chemical extraction methods (soil-test methods) could be used to estimate such P fertilizer applications (Jones and Fox 1977; Hue, Ikawa, and Huang 2000).

Several $\mathrm{P}$ extraction methods using acids, organic and inorganic complexing agents, or alkaline solutions have been developed as reviewed by Fixen and Grove (1990). The extractants often extract all or part of the labile $\mathrm{P}$, which is considered available to plants during their growth cycle, plus an undefined proportion of other forms of soil P. Because several soil properties influence the extraction of $\mathrm{P}$, it is not surprising that there is no one best extractant at all conditions (Thomas and Peaslee 1973; Fox 1992).

It seems that $\mathrm{P}$ sorption isotherms have a distinct advantage over extraction methods in predicting the efficiency of plants to utilize the $\mathrm{P}$ that is available (Ozanne and Shaw 1968; Fox and Kang 1978). Yet, constructing such isotherms is time-consuming and so is poorly suited to soil-test operations where a rapid response is usually expected. The objective of this work was to establish a good relationship between soil solution $\mathrm{P}$ and chemically extractable $\mathrm{P}$, so that it is possible to quickly predict, albeit roughly, (1) whether a soil needs additional $\mathrm{P}$ and (2) if it does, the quantity of $\mathrm{P}$ needed for good growth of a given crop.

\section{Materials and Methods}

\section{Soil Collection, Characterization, and Preparation}

Twelve surface $(1-10 \mathrm{~cm})$ samples of 11 soil series were collected from Kauai, Oahu, and Hawaii islands of the state of Hawaii. Their taxonomic classifications are listed in Table 1. The soils were air dried and crushed to pass through a 1-mm (20-mesh) 
Table 1. Soils used in the experiment and their taxonomic classification (Hue et al. 2007)

\begin{tabular}{|c|c|c|c|}
\hline Soil series & Orders & Family & $\begin{array}{l}\text { Island } \\
\text { location }\end{array}$ \\
\hline 1. Alealoa & Ultisols & $\begin{array}{l}\text { Fine, parasesquic, isohyperthermic, } \\
\text { ustic palehumults }\end{array}$ & Oahu \\
\hline $\begin{array}{l}\text { 2. Halii } \\
\text { (cultivated) }\end{array}$ & Oxisols & $\begin{array}{l}\text { Fine, mixed, active, isohyperthermic } \\
\text { cumulic haplustolls }\end{array}$ & Kauai \\
\hline $\begin{array}{l}\text { 3. Halii } \\
\text { (uncultivated) }\end{array}$ & Oxisols & $\begin{array}{l}\text { Fine, mixed, active, isohyperthermic } \\
\text { cumulic haplustolls }\end{array}$ & Kauai \\
\hline 4. Hanalei & Inceptisols & $\begin{array}{l}\text { Very fine, mixed, isohyperthermic } \\
\text { typic endoaquepts }\end{array}$ & Kauai \\
\hline 5. Kaiwiki & Andisols & $\begin{array}{l}\text { Hydrous, ferrihydritic, isothermic } \\
\text { acrudoxy hydrudands }\end{array}$ & Hawaii \\
\hline 6. Kaneohe & Oxisols & $\begin{array}{l}\text { Fine, kaolinitic, isohyperthermic } \\
\text { typic eutrotorrox }\end{array}$ & Oahu \\
\hline 7. Kapaa & Oxisols & $\begin{array}{l}\text { Very fine, ferruginous, } \\
\text { isohyperthermic rhodic acrudox }\end{array}$ & Kauai \\
\hline 8. Lihue & Oxisols & $\begin{array}{l}\text { Very fine, ferruginous, } \\
\text { isohyperthermic rhodic entrustox }\end{array}$ & Kauai \\
\hline 9. Mahana & Oxisols & $\begin{array}{l}\text { Very fine, mixed, isothermic inceptic } \\
\text { haplustox }\end{array}$ & Kauai \\
\hline 10. Makapili & Oxisols & $\begin{array}{l}\text { Very fine, isohyperthermic anionic } \\
\text { acrudox }\end{array}$ & Kauai \\
\hline 11. Pooku & Oxisols & $\begin{array}{l}\text { Very fine, isohyperthermic anionic } \\
\text { acrudox }\end{array}$ & Kauai \\
\hline 12.Tantalus & Andisols & Medial, isothermic typic hapludands & Oahu \\
\hline
\end{tabular}

sieve. Moisture content was determined after oven drying 10 -g samples at $105{ }^{\circ} \mathrm{C}$ for $24 \mathrm{~h}$. The screened, air-dried soil samples were stored at $25^{\circ} \mathrm{C}$ for $\mathrm{P}$ sorption study and chemical extraction.

\section{Phosphorus Sorption Isotherm}

Three-g samples, oven-dry equivalent, were equilibrated with $30 \mathrm{~mL}$ of $0.01 \mathrm{M}$ calcium chloride $\left(\mathrm{CaCl}_{2}\right)$ containing various amounts of $\mathrm{P}$ for 6 days, as described by Fox and Kamprath (1970). Phosphorus remaining in solution after equilibration and centrifugation was determined colorimetrically using the method of Murphy and Riley (1962). Phosphorus disappearing from solution was considered sorbed. Phosphate sorption curves ( $\mathrm{P}$ sorbed vs. $\mathrm{P}$ in solution at equilibrium) were constructed from these data.

\section{Chemical Extractions (Soil Test) for P}

1. Mehlich 3 extraction procedure (Mehlich 1984). This solution consists of $0.015 \mathrm{M}$ ammonium fluoride $\left(\mathrm{NH}_{4} \mathrm{~F}\right), 0.2 \mathrm{M}$ acetic acid $\left(\mathrm{CH}_{3} \mathrm{COOH}\right), 0.25 \mathrm{M}$ 
ammonium nitrate $\left(\mathrm{NH}_{4} \mathrm{NO}_{3}\right), 0.013 \mathrm{M}$ nitric acid $\left(\mathrm{HNO}_{3}\right)$, and $0.001 \mathrm{M}$ ethylenediaminetetraacetic acid (EDTA). Two g of soil and $20 \mathrm{~mL}$ of solution were shaken for $5 \mathrm{~min}$, the suspension was filtered, and $\mathrm{P}$ in the filtrate was measured.

2. Olsen extraction procedure (Olsen et al. 1954). Soil $\mathrm{P}$ was extracted from $2.5 \mathrm{~g}$ soil with $50 \mathrm{~mL}$ of $0.5 \mathrm{M}$ sodium bicarbonate $\left(\mathrm{NaHCO}_{3}\right)$, adjusted to $\mathrm{pH} 8.5$. The mixture was shaken for $30 \mathrm{~min}$, the suspension was filtered, and the filtrate was acidified before $\mathrm{P}$ was measured.

3. Modified Truog procedure (Hue, Uchida, and Ho 2000). The P in $0.50 \mathrm{~g}$ of soil is extracted with $50 \mathrm{~mL}$ of a solution consisting of $0.01 \mathrm{M}$ sulfuric acid $\left(\mathrm{H}_{2} \mathrm{SO}_{4}\right)$ and $0.02 \mathrm{M}$ ammonium sulfate $\left[\left(\mathrm{NH}_{4}\right)_{2} \mathrm{SO}_{4}\right]$. The mixture was shaken for $30 \mathrm{~min}$, the suspension was filtered, and $\mathrm{P}$ in the filtrate was measured.

Table 2. Concentrations of soil solution $P$ associated with near maximum yields of several crops (data are from field experiments conducted in Hawaii, except as noted)

\begin{tabular}{lc}
\hline Crop & $\begin{array}{c}\text { Soil solution P } \\
\left(\mathrm{mg} \mathrm{P} \mathrm{L}^{-1}\right)\end{array}$ \\
\hline Sugarcane (Saccharum officinarum) & 0.01 \\
Sorghum (Sorghum bicolor) & 0.06 \\
Low solar radiation & 0.01 \\
Corn (Zea mays) & 0.05 \\
Wheat (Triticum aestivum) [calcareous soil, Pakistan] & 0.035 \\
Rice (Oriza sativa) [flooded pots, IRRI, Philippines] & 0.02 \\
Millet (Pennisetum glaucum) & 0.20 \\
Rye grass (Lolium perene) [New Zealand, pots] & 0.10 \\
Peanut (Arachis hypogaea) [Halii soil] & 0.01 \\
Soybean (Glycine max) & 0.20 \\
Desmodium (Desmodium intortum) [Honokaa soil] & 0.20 \\
Cowpea (Vigna unguiculata) & 0.10 \\
White clover (Trifolium repens) [New Zealand, pots] & 0.30 \\
Head lettuce (Lactuca sativa) & 0.30 \\
Chinese cabbage (Brassica oleracea) & 0.20 \\
Tomato (Lycopersicon esculentum) & 0.20 \\
Eggplant (Solanum melongena) & 0.20 \\
Onion (Allium cepa) mycorrhizal & 0.40 \\
Nonmycorrhizal & 1.6 \\
Cassava (Manihot esculenta) & 0.005 \\
Sweet potato (Ipomea batatas) & 0.10 \\
Irish potato (Solanum tuberosum) [Mean of five national and & 0.18 \\
international locations] & \\
Taro (Colocasia esculenta) [not flooded, Kauai] & 0.05 \\
[flooded, Kauai] & 0.07 \\
Yams (Dioscorea alata) & 0.05 \\
Banana (Musa paradisiacal) [100-L pots] & 0.05 \\
Macadamia (Macadamia intergrifolia) [20-L pots] & 0.008 \\
Chrysanthemum (Chrysanthemum morifolium) [Maui] & 0.17 \\
\hline
\end{tabular}


Reported P Concentrations in Soil Solution associated with Near (95\%) Maximum Yields

Data on the relationship between $\mathrm{P}$ concentration and yield were collected mostly from the work of Fox and co-workers (Fox 1979, 1981; Fox and Kamprath 1970; Fox and Kang 1978; Fox et al. 1974; Fox, Plunknett, and Whitney 1968; Fox, Saunders, and Rajan 1986; Lin and Fox 1987; Memon and Fox 1983; Memon, Puno, and Fox 1991; Nishimoto, Fox, and Parvin 1977; Peaslee and Fox 1978; Roy and DeDatta 1985; Vander Zaag et al. 1979). These $P$ critical levels (Table 2) range from $0.005 \mathrm{mg} \mathrm{L}^{-1}$ for mycorrhizal cassava to 0.20 for nonmycorrhizal cassava and 0.40 for mycorrhizal onions to 1.6 for nonmycorrhizal onions. The yield response curves for corn growing on two Hawaii soils of different mineralogy were almost identical (Figure 1), which demonstrates the predictive value of $\mathrm{P}$ sorption curves for different soil conditions (Fox, Yost, and Memon 1982).

\section{Results and Discussion}

\section{Phosphorus Sorption Isotherms}

The $\mathrm{P}$ sorption isotherms of the 12 soils studied are shown in Figure 2. Because the soil have different mineralogies, their $\mathrm{P}$ sorption properties are understandably

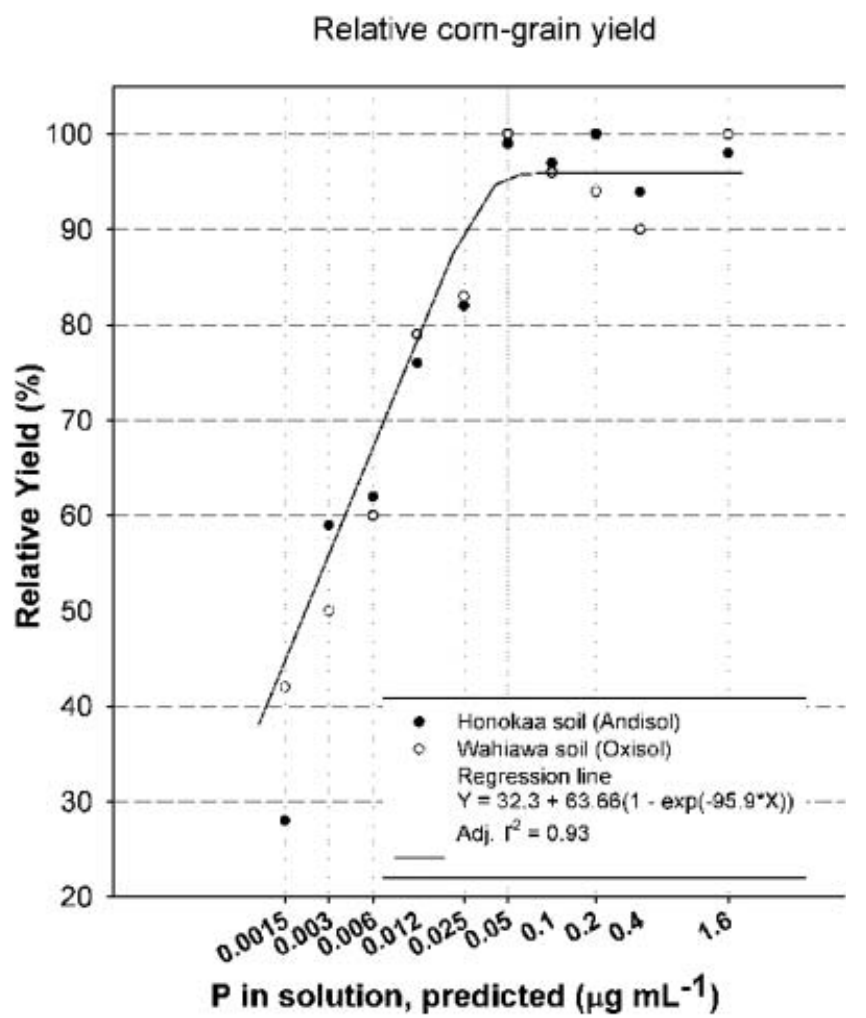

Figure 1. Relationship between $P$ in the soil solution and corn yield for two Hawaii soils of different mineralogy. The data are from Fox et al. (1982). 

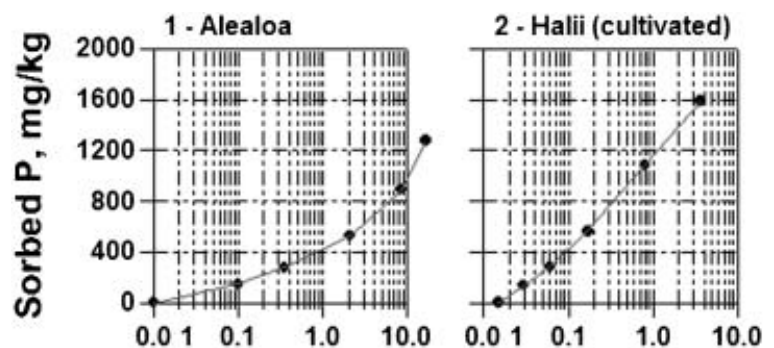

3 - Halii (uncult)
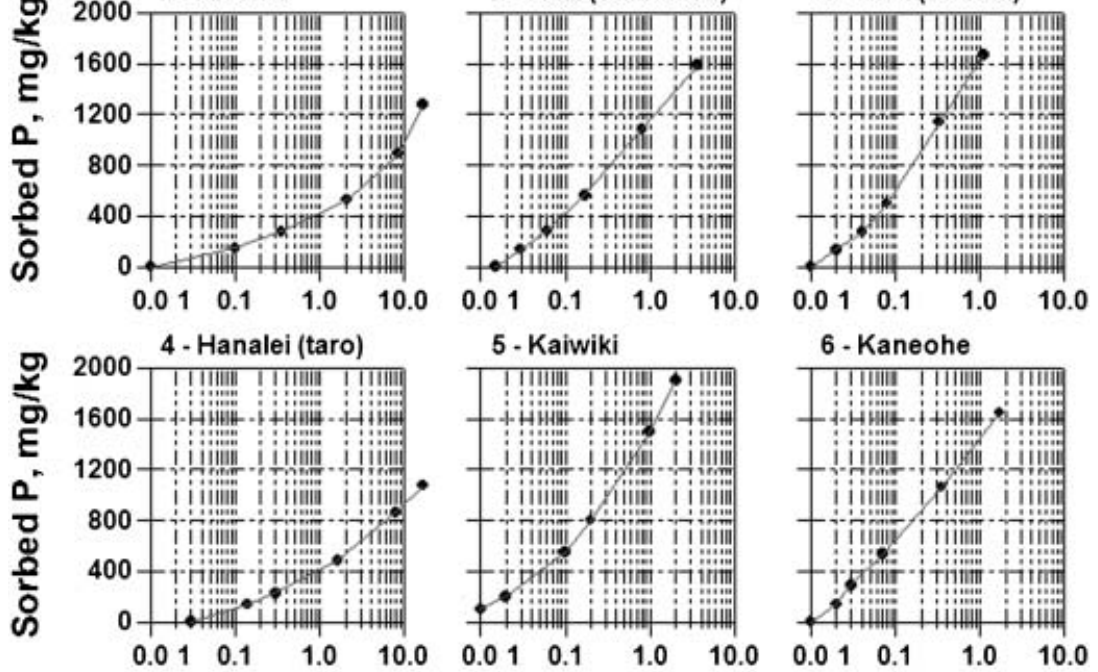

6-Kaneohe
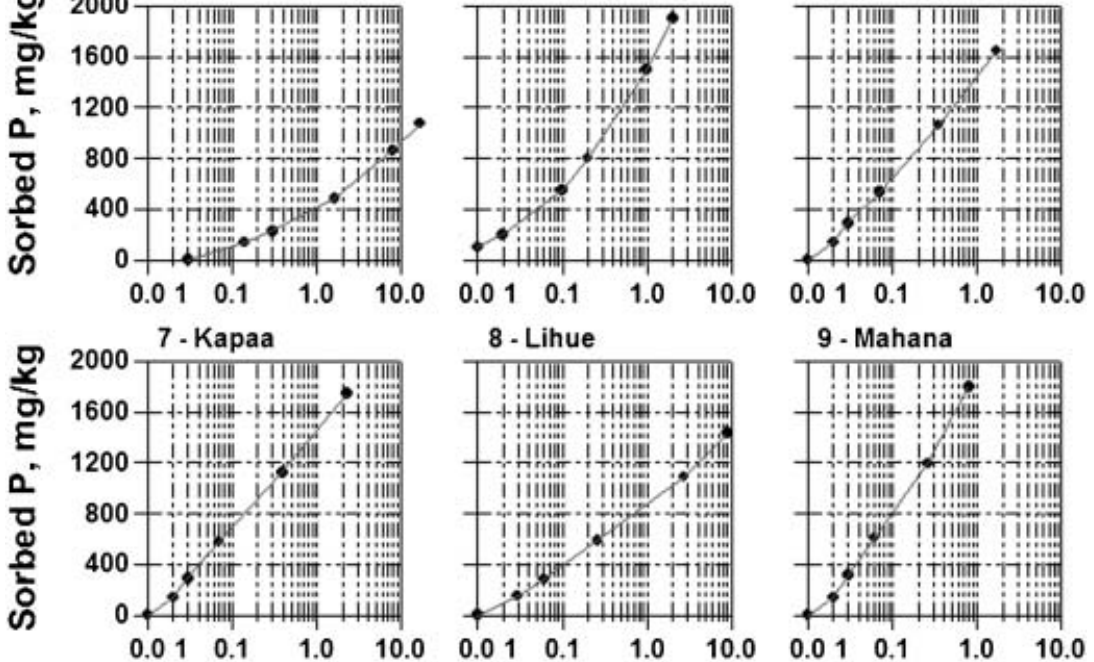

8 - Lihue

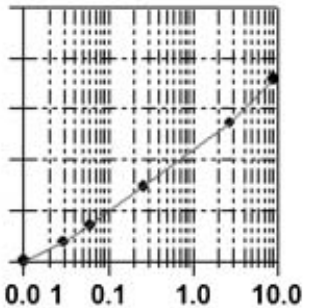

9 - Mahana

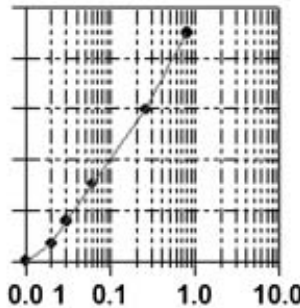

11 - Pooku

12. Tantalus
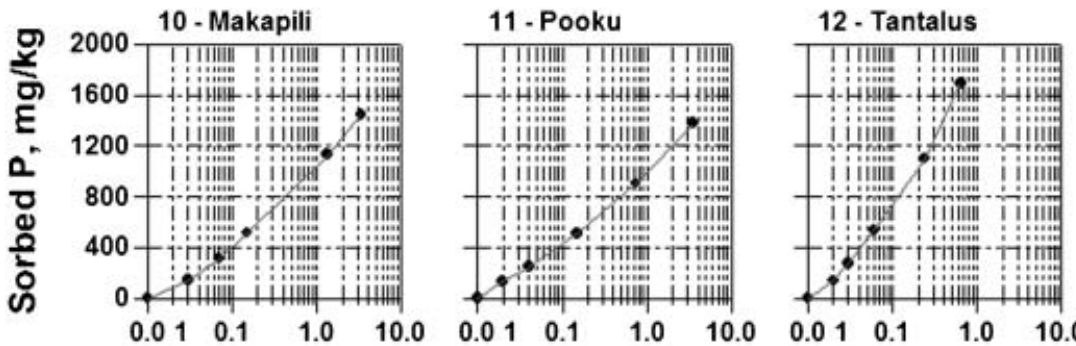

Solution P, mg/L

$\begin{array}{llll}0.01 & 0.1 & 1.0 & 10.0\end{array}$

Figure 2. Phosphorus sorption isotherms for 12 soils of Hawaii.

different. For example, to maintain $0.10 \mathrm{mg} \mathrm{PL}^{-1}$ in the equilibrating solution (a level we believe to be adequate for most crops), the concentration of $0.20 \mathrm{mg} \mathrm{P} \mathrm{L}^{-1}$, as originally proposed by Beckwith (1965) for comparing the sorption capacities of soils, seems more than adequate for most crop requirements (as Table 2 shows). The Aleoloa and Hanalei soils (curves 1 and 4) sorb only $200 \mathrm{mg} \mathrm{kg}^{-1}$. In contrast, the cultivated Halii soil sorbs $400 \mathrm{mg} \mathrm{P} \mathrm{kg}^{-1}$, and the uncultivated Halii sorbs 600 (curves 2 and 3). With past $\mathrm{P}$ fertilization, the isotherm usually shifts to the right, as observed by Jones and Fox (1977); that explains the lower P sorption in the cultivated Halii soil vs. its uncultivated counterpart. For Andisols, such as the 
Tantalus (curve 12), which contains a high quantity of amorphous alumino silicates (allophane), nearly $800 \mathrm{mg} \mathrm{kg}^{-1}$ of $\mathrm{P}$ is sorbed to yield $0.10 \mathrm{mg} \mathrm{P} \mathrm{L}^{-1}$ in solution.

\section{Correlating Extractable P with P Sorption Curves}

The first step in soil testing is to distinguish between P-deficient and nondeficient soils. Normally this task would require growing plants at various $\mathrm{P}$ levels and measuring soil $\mathrm{P}$ by certain extractants, then making a correlation between plant growth/yield and extracted P. From such results, critical P levels (extracted P
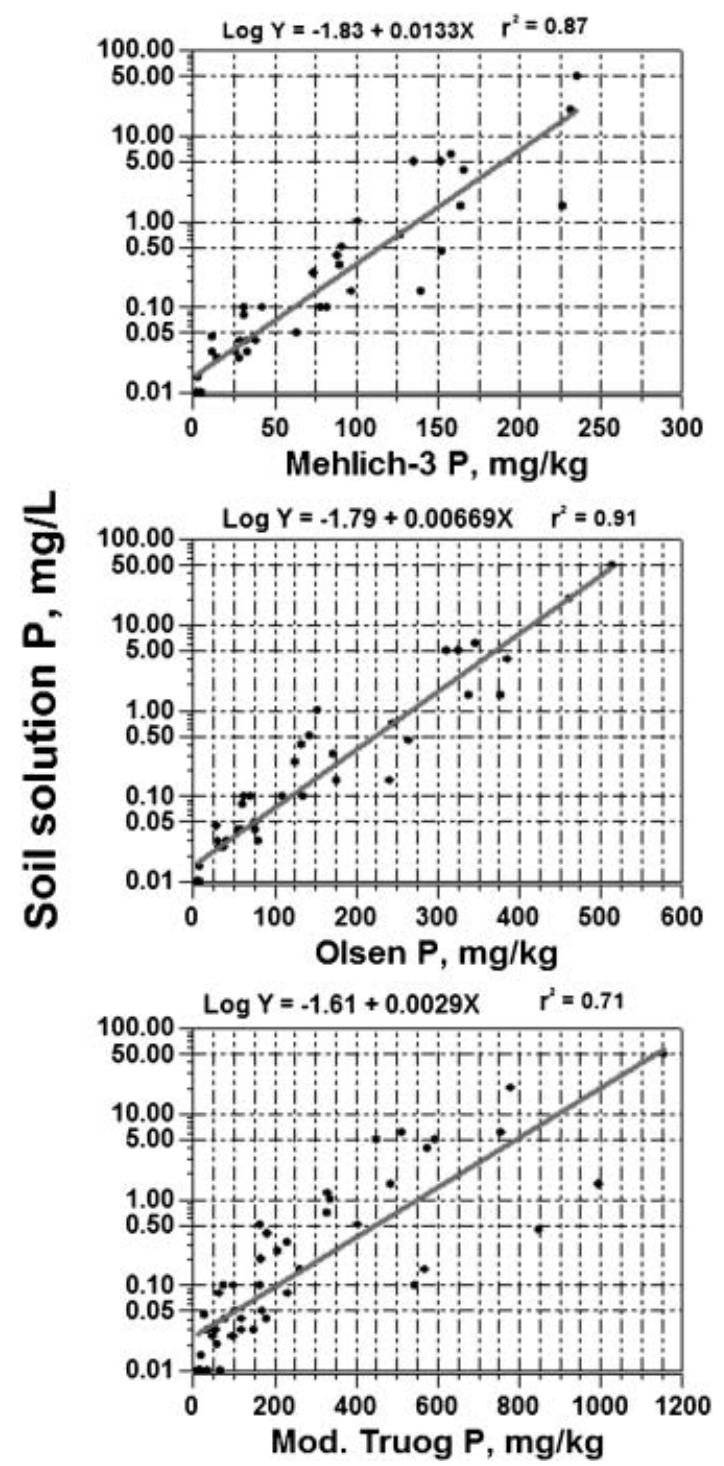

Figure 3. Relationship between soil solution $\mathrm{P}$ and extractable (soil-test) $\mathrm{P}$. 
concentration at $95 \%$ maximum yield) would be identified. However, because critical $\mathrm{P}$ levels of many soil-crop combinations have been established for $\mathrm{P}$ sorption isotherms (Table 2), relationships between $\mathrm{P}$ in solution as established by the $\mathrm{P}$ sorption procedure and $\mathrm{P}$ extracted by chemical solution could be connected. This approach would save time and resources. Figure 3 shows such relationships for the Mehlich 3, Olsen, and modified Truog procedures for the 12 soils of Hawaii.

On a semi-log scale, the relationship appears linear for all three extractants, and the Olsen method seems most correlated with soil solution $\mathrm{P}\left(\mathrm{r}^{2}=0.91\right)$. This finding agrees with those observed by Kamprath and Watson (1980) and Fox, Yost, and Memon (1982). Given the strong nature of the Olsen solution [0.5 M sodium bicarbonate $\left(\mathrm{NaHCO}_{3}\right), \mathrm{pH}$ 8.5], this extractant can remove $\mathrm{P}$ from several forms, including aluminum (Al) $\mathrm{P}$, calcium (Ca) $\mathrm{P}$, and to a lesser extent, $\mathrm{P}$ adsorbed on iron-hydrated oxides (Kamprath and Watson 1980). Actually, all the three soil-test methods performed rather well on the 12 soils tested (Figure $3, \mathrm{r}^{2}$ ranges from 0.71 to

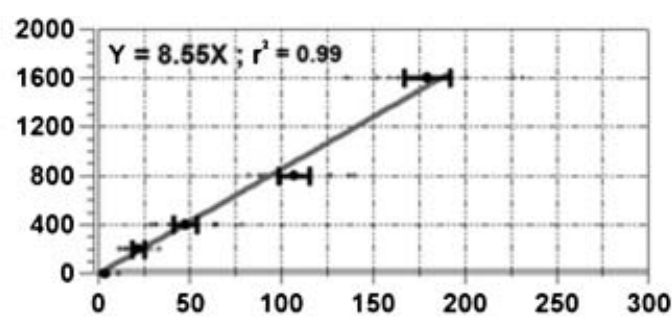

Mehlich-3 P, mg/kg
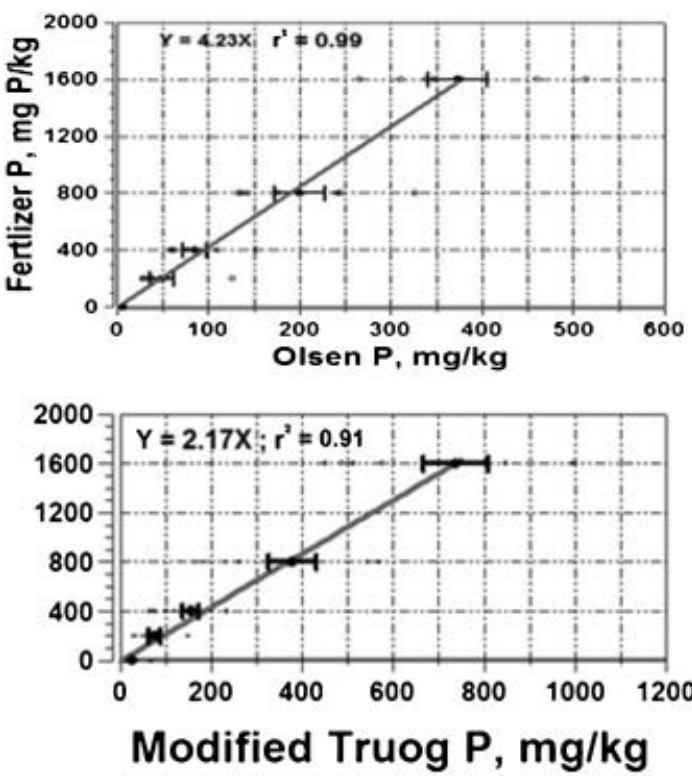

Figure 4. Relationship between $\mathrm{P}$ extracted by three soil-test methods and fertilizer $\mathrm{P}$. Horizontal bars are standard errors of the means of extractable P. Open circles are data for individual soils. 
0.91). It should be noted that their extraction strengths were different: For example, to maintain $0.10 \mathrm{mg} \mathrm{PL}^{-1}$ in the soil solution, it would require 60,110 , and $200 \mathrm{mg} \mathrm{P} \mathrm{kg}^{-1}$ as extracted by the Mehlich 3, Olsen, and modified Truog, respectively.

\section{Establishing Relationships between Extractable $P$ and Fertilizer P Additions}

Predicting fertilizer requirements based on extractable $\mathrm{P}$ values is not easy. That is because it involves specific soil and crop interactions. Traditionally, such predictions require calibration works in which results of crop performance are plotted against extracted $\mathrm{P}$ for important soil-crop conditions that may be encountered in a specific area. To save time, labor, and resources, we propose, as a first approximation, to establish relationships between extractable $\mathrm{P}$ and $\mathrm{P}$ fertilizer added in laboratory settings. Figure 4 shows such relationships for the 12 Hawaii soils tested. This would allow estimating $\mathrm{P}$ buffer coefficients (ratio of fertilizer $\mathrm{P}$ to extractable $\mathrm{P}$ or the slope of regression lines in Figure 4) for some agriculturally important soils of Hawaii. Evidently, different extractants/procedures yield different buffer coefficients: it was 8.6, 4.2, and 2.2 for the Mehlich 3, Olsen, and modified Truog, respectively. It should be noted that these $\mathrm{P}$ buffer coefficients may be changed with soil texture and mineralogies (e.g., smectite vs. iron oxides vs. allophane) and time after $\mathrm{P}$ fertilization.

In summary, with an extractable $P$ value obtained from a soil testing laboratory, (i) Figure 3 can be used to determine soil solution P, (ii) Table 2 can be used to find out the critical soil solution $\mathrm{P}$ required for a specific crop and whether the soil is $\mathrm{P}$ sufficient, (iii) critical soil solution $\mathrm{P}$ obtained from Table 2 is matched with the corresponding extractable $\mathrm{P}$ of Figure 3, and finally, (iv) Figure 4 can be used to determine the amount of fertilizer $\mathrm{P}$ needed for application.

\section{References}

Asher, C. J., and J. K. Loneragan. 1967. Response of plants to phosphate concentrations in solution cultures, I: Growth and phosphorus contents. Soil Science 103:225-233.

Beckwith, R. S. 1965. Sorbed phosphate at standard supernatant concentration as an estimate of phosphate needs of soils. Australian Journal of Experimental Agriculture and Animal Husbandry 5:52-58.

Fixen, P. E., and J. H. Grove. 1990. Testing soils for phosphorus. In Soil testing and plant analysis, ed. R. L. Westerman, 141-180. Madison, Wisc.: Soil Science Society of America, Inc.

Fox, R. L. 1979. Comparative response of field grown crops to phosphate concentrations in soil solution. In Stress physiology in crop plants, ed. H. Mussell, and R. Staples, 81-106. New York: Wiley.

Fox, R. L. 1981. External phosphorus requirements of crops. Chap. 12. pp. 223-233. Chemistry in the soil environment, ed. R. R. Dowdy et al., 223-233. Madison, Wisc.: Soil Science Society of America.

Fox, R. L. 1992. Predicting plant nutrient requirements-A rational approach. In Proceedings of the International Symposium Nutrient Management for Sustained Productivity, 1, 4354. Ludhiana, India: Department of Soils, Punjab Agricultural University.

Fox, R. L., and E. J. Kamprath. 1970. Phosphate sorption isotherms for evaluating the phosphate requirements of soils. Soil Science Society of America Proceedings 34:902-907.

Fox, R. L., and B. T. Kang. 1978. Influence of phosphorus fertilizer placement and fertilization rate on maize nutrition. Soil Science 125:134-140. 
Fox, R. L., R. K. Nishimoto, J. K. Thompson, and R. S. de la Pena. 1974. Comparative external $\mathrm{P}$ requirement of plants growing in tropical soils. In Transaction of the 10th International Congress of Soil Science, 4, 232-239. Moscow, Russia: Izd. Nauka.

Fox, R. L., D. L. Plucknett, and A. S. Whitney. 1968. Phosphate requirements of Hawaiian latosols. Transaction of the 9th International Congress of Soil Science, 2, 301-310. Adelaide, Australia: Elsevier.

Fox, R. L., W. M. H. Saunders, and S. S. Rajan. 1986. Phosphorus nutrition of pasture species: Phosphorus requirements and root saturation values. Soil Science Society of America Journal 50:142-148.

Fox, R. L., R. S. Yost, and K. S. Memon. 1982. Estimating phosphate fertilizer requirements in the tropics: Some tentative observations. In Phosphorus and potassium in the tropics, ed. L. Pushparajah, and H. A. Sharifuddin, 335-363. Kuala Lumpur: Malaysian Society of Soil Science.

Hue, N. V., G. Uehara, R. S. Yost, and M. Ortiz-Escobar. 2007. Distribution of soil orders in Hawaii. Journal of Hawaiian and Pacific Agriculture 14:17-29.

Hue, N. V., H. Ikawa, and X. Huang. 2000. Predicting soil phosphorus requirements. In Plant nutrient management in Hawaii soils, ed. J. A. Silva and R. Uchida, 95-99. Honolulu: College of Tropical Agriculture and Human Resources, University of Hawaii.

Hue, N. V., R. Uchida, and M. C. Ho. 2000. Sampling and analysis of soils and plant tissues: How to take representative samples, how the samples are tested. Plant nutrient management in Hawaii soils, ed. J. A. Silva and R. Uchida, 23-30. Honolulu: College of Tropical Agriculture and Human Resources, University of Hawaii.

Jones Jr, J. B., B. Wolf, and H. A. Mills. 1991. Plant analysis handbook. Athens, Ga.: MicroMacro Publishers.

Jones, J. P., and R. L. Fox. 1977. Phosphate sorption curves as a soil testing technique: A simplified approach. Communications in Soil Science and Plant Analysis 8:209-219.

Kamprath, E. J., and M. E. Watson. 1980. Conventional soil and tissue tests for assessing the phosphorus status of soils. In The role of phosphorus in agriculture, ed. F. E. Khasawneh et al., 433-469. Madison, Wisc.: Soil Science Society of America, Inc.

Lin, M. L., and R. L. Fox. 1987. External and internal P requirements of mycorrhizal and non-mycorrhizal banana (Musa sapientum). Journal of Plant Nutrition 10:1341-1348.

Marschner, H. 1995. Mineral nutrition of higher plants. San Diego, Calif.: Academic Press.

Mehlich, A. 1984. Mehlich 3 soil test extractant: A modification of Mehlich 2 extractant. Communications in Soil Science and Plant Analysis 15:1409-1416.

Memon, K. S., and R. L. Fox. 1983. Utility of phosphate sorption curves in estimating the phosphorus requirements of cereal crops: Wheat (Triticum aestivum). Paper presented at the Third International Congress on Phosphorus Compounds, Brussels, Oct. 4-6.

Memon, K. S., H. K. Puno, and R. L. Fox. 1991. Phosphate sorption approach for determining phosphorus requirements in calcareous soils. Fertilizer Research 28:67-72.

Murphy, F., and J. P. Riley. 1962. A modified single solution method for the determination of phosphate in natural waters. Analytica Chemica Acta 27:31-36.

Nishimoto, R. K., R. L. Fox, and P. F. Parvin. 1977. Response of vegetable crops to phosphorus concentrations in soil solution. Journal of American Society of Horticulture Science 102:705-709.

Olsen, S. R., C. V. Cole, F. S. Watanabe, and L. A. Dean. 1954. Estimation of available phosphorus in soils by extraction with sodium bicarbonate (USDA Circular 939). Washington, D.C.: U.S. Government Printing Office.

Ozanne, P. G., and T. C. Shaw. 1968. Advantage of the recently developed phosphate sorption test over the older extraction methods for soil phosphate. In Transaction of the Ninth International Congress of Soil Science, vol. 2, pp. 273-280. Adelaide, Australia: Elsevier.

Peaslee, D. E., and R. L. Fox. 1978. Phosphorus fertilizer requirements as estimated by phosphate sorption. Communications in Soil Science and Plant Analysis 9:975-993. 
Roy, A. C., and S. K. DeDatta. 1985. Phosphate sorption isotherms for evaluating phosphorus requirements of wetland rice soils. Plant and Soil 86:185-196.

Thomas, G. W., and D. E. Peaslee. 1973. Testing soils for phosphorus. In Soil testing and plant analysis, ed. L. M. Walsh and J. D. Beaton, 115-132. Madison, Wisc.: Soil Science Society of America, Inc.

Uchida, R. 2000. Essential nutrients for plant growth: Nutrient functions and deficiency symptoms. In Plant nutrient management in Hawaii soils, ed. J. A. Silva and R. Uchida, 31-55. Honolulu: College of Tropical Agriculture and Human Resources, University of Hawaii.

Vander Zaag, P., R. L. Fox, R. de la Pena, W. M. Laughlin, A. Rhyskamp, S. Villagarcia, and D. T. Westermann. 1979. The utility of phosphate sorption curves for transferring soil management information. Tropical Agriculture (Trinidad) 56:153-160. 